\title{
Clinical and biochemical assessments of damage due to perinatal asphyxia: a double blind trial of a quantitative method
}

\author{
I LAING, * J K BROWN, * R A HARKNESS \\ From the *Department of Child Life and Health and Simpson Memorial Maternity Pavilion, University of \\ Edinburgh, and Division of Inherited Metabolic Diseases, Medical Research Council, Clinical Research Centre, \\ Harrow, Middlesex
}

SUMMARY Using conventional criteria, a series of 26 infants was selected for intrapartum asphyxia from about 4000 deliveries over one year at a single hospital to assess the efficacy of a new biochemical method. Tissue damage was estimated from urinary excretion of hypoxanthine, an important and central intermediate in purine metabolism. The overall pattern showed agreement between the grading (by previously accepted methods) of asphyxia in the perinatal period and our new biochemical approach. The association with handicap at one year of age following asphyxia was complex.

This biochemical technique could be used to exclude postasphyxial damage as a cause of clinical disturbances and to select a small group ( $0 \cdot 1 \%$ of all births) who require further investigation for rarer disorders which may also cause long term handicap.

Intrapartum asphyxia is a principal cause of perinatal morbidity and is usually the cause of obstetric intervention.' Present techniques for assessing intrapartum asphyxia are unsatisfactory. ${ }^{23}$ Asphyxia can be defined at the molecular level: it is a failure of energy supply, sufficient to cause cellular damage. As the energy currency of cells is the purine nucleotide adenosine triphosphate (ATP) the definition is ATP depletion sufficient to cause irreversible or partially reversible cellular damage. ATP is confined to living cells but its depletion can be measured in extracellular fluids when the output of hypoxanthine from tissues into blood, urine, amniotic fluid and cerebrospinal fluid increases. Mechanisms and quantitative associations between concentrations of the central intermediate in purine metabolism, hypoxanthine, and tissue energy supply have been established. ${ }^{4-9}$ The association between ATP depletion and subsequent tissue damage is more difficult to quantify. ${ }^{10} 11$ The transitions between stages of the sequence of events in intrapartum asphyxia can be independently controlled. It is obvious that predisposing causes like the factor(s) causing fetal growth retardation need not be associated with asphyxia if compensatory mechanisms like increased haemoglobin synthesis, and more

Accepted for publication 16 September 1987 acutely, fetal tachycardia are adequate to ensure oxygen delivery. If cord occlusion has occurred then decompensation with asphyxia (fetal ATP depletion) might occur. ATP concentrations may recover, especially if there is early obstetric intervention. If ATP depletion is severe and prolonged tissue damage may occur. The infant may then die or may completely recover from the tissue damage; more rarely, some permanent defect may be sustained.

Unexpectedly, there is a close positive correlation between neurological damage, assessed clinically in the neonatal period, and persistently excessive hypoxanthine excretion occurring 24 hours after ATP depletion and lasting for several days ${ }^{12}$; this presumably reflects the renal damage known to occur after asphyxia. This persistent change must have a different basis to the increased hypoxanthine output occurring in the first six to 12 hours after ATP depletion. Hypoxanthine excretion can be measured as a hypoxanthine:creatinine concentration ratio, ${ }^{13}$ and an incomplete urine sample using a non-invasive method can therefore be used to estimate quantitatively tissue damage after ATP depletion.

As the application of published findings would seem to solve the widely recognised problem of the quantitation of postasphyxial damage in brain and kidney ${ }^{214} 15$ we undertook a detailed double blind trial in a second clinical centre. The duration of the study and sample 
size were comparable with those of the previous study, ${ }^{12}$ but to determine the association between our neonatal assessments of damage and persistent handicap we added developmental assessments at the age of one year.

\section{Material and methods}

Between July 1984 and June 1985, all infants weighing greater than $1500 \mathrm{~g}$ at birth, who were admitted to the special care baby unit at the Simpson Memorial Maternity Pavilion with a clinical diagnosis of birth asphyxia were included in the study. Informed parental consent was obtained.

Between 10 am and 8 pm on day 2 of life a 10 hour sample of urine uncontaminated with meconium was collected and stored at $-20^{\circ} \mathrm{C}$. From our previous results, urine should have ideally been collected between 24 and 48 hours of life; our compromise avoided the collection of urine by night staff.

At the time of discharge from the unit, each infant's course was documented on a standard form, and the cerebral asphyxia designated mild, moderate, or severe. Renal and hepatic damage were also assessed at this time. The severity of the asphyxia was estimated from obstetric evidence, including fetal heart rate abnormalities, meconium staining of amniotic fluid, and from neonatal evidence. This included Apgar scores, clinical examination, fits, blood $\mathrm{pH}$ and gas concentrations, and chemical evidence of renal or hepatic damage or both, raised serum creatinine and alanine aminotransferase activity.

One year after the expected date of delivery the parents were invited to bring the children for follow up at the outpatient clinic. A full history was obtained, and the child examined for neurological and developmental abnormality according to a standardised procedure. $^{16}$

Developmental assessments of 21 infants at 1 year of age were performed by one of us (IL) at an Edinburgh outpatient clinic. Two infants were seen by other paediatricians 80 and 350 miles from Edinburgh. Two mothers were unable to bring their children in for medical examination but filled in a detailed questionnaire.

Complete urine collections were analysed for hypoxanthine and xanthine by the methods of Harkness, Whitelaw, and Simmonds ${ }^{12}$ and Simmonds and Harkness. ${ }^{17}$ Outputs were corrected for the duration of the collection and for the infants' body weight ${ }^{18}$; results are therefore expressed in nmol hour $/ \mathrm{kg}$ body weight. Creatinine was estimated colourimetrically using picric acid (Sigma, Poole, Dorset). Urinary hypoxanthine $(\mu \mathrm{mol} / \mathrm{l})$ :creatinine $(\mathrm{mmol} / \mathrm{l})$ ratios were comparable therefore with those from neonates at Northwick Park Hospital. ${ }^{13}$ These results were separated into normal and abnormal values from existing reference values and the completed lists filed by a third party in another centre. When all examinations had been completed results were exchanged and compared.

These studies were conducted with the approval of the ethical committee of the Simpson Memorial Maternity Pavillion.

\section{Results}

After the results were exchanged and grouped (table 1) it was clear that there was overall agreement (tables 2 and 3) with some interesting exceptions (tables 4 and 5).

The previously accepted clinical and biochemical assessments of the severity of asphyxia in the newborn and their subsequent development at the age of 1 year were grouped with our new biochemical estimates of the damage after ATP depletion from hypoxanthine excretion. Table 2 shows that 11 infants were normal by both clinical and our biochemical method with normal development at 1 year of age. Table 3 shows that six infants showed moderate or severe asphyxia by existing criteria and by our biochemical method. One of these infants died before follow up and two showed some abnormalities in their development; three, however, showed normal development. Seventeen of the 26 infants showed the predicted pattern of results (figure). The results do not form a continuous distribution with an arbitrary division made by the upper limit of the reference values. The values obtained from a series of 16 normal infants nursed in postnatal wards at Northwick Park Hospital are also shown in table $2 .{ }^{13}$ The upper limits (95th centile) of these normal values are indicated by the interrupted vertical lines in the figure.

It was expected that a sensitive quantitative variable would show abnormalities in some infants judged by existing means to be only mildly asphyxiated. This is the pattern in table 4 which shows that cases 18 and 19 were clearly biochemically abnormal with consistent results for the hypoxanthine creatinine concentration ratios and total excretions of both hypoxanthine and xanthine. Cases 20 and 21 had normal hypoxanthine: creatinine concentration ratios and were clinically only mildly asphyxiated with normal development.

Table 5 details those babies who were clinically moderately or severely asphyxiated or developmentally abnormal but were normal by our biochemical method. The distribution of results suggests, however, that case 22 may have had an abnormal hypoxanthine: creatinine concentration ratio $(23.4)$ because this value is an outlier. Similarly, case 26 may have had an abnormal total hypoxanthine excretion $(38.5 \mathrm{nmol} /$ hour $/ \mathrm{kg}$ body weight) (table 5). Cases, 23, 24, and 25 
Table 1 Grouping of results

\begin{tabular}{lll}
\hline $\begin{array}{l}\text { Standard clinical and biochemical } \\
\text { assessment of asphyxia }\end{array}$ & $\begin{array}{l}\text { New biochemical assessment of } \\
\text { asphyxial damage }\end{array}$ & $\begin{array}{l}\text { No of } \\
\text { infants }\end{array}$ \\
\hline Mild & None-normal & Normal \\
$\begin{array}{l}\text { Moderate or severe } \\
\text { Mild }\end{array}$ & $\begin{array}{l}\text { Definite-abnormal } \\
\text { Moderate or severe }\end{array}$ & Some abnormality \\
Normal or variable & Variable & Normal \\
\end{tabular}

Table 2 Intrapartum asphyxia: clinically mild cerebral asphyxia with normal development at 1 year and normal hypoxanthine excretion

\begin{tabular}{|c|c|c|c|c|c|c|}
\hline Case No & $\begin{array}{l}\text { Gestational } \\
\text { age (weeks) }\end{array}$ & Weight (g) & $\begin{array}{l}\text { Hypoxanthine: } \\
\text { creatinine ratio }\end{array}$ & $\begin{array}{l}\text { Hypoxanthine } \\
\text { excretion } \\
\text { (nmol/hour/kg) }\end{array}$ & $\begin{array}{l}\text { Xanthine } \\
\text { excretion } \\
\text { nmol/hour/kg }\end{array}$ & Remarks \\
\hline $\begin{array}{c}1 \\
2 \\
3 \\
4 \\
5 \\
6 \\
7 \\
8 \\
9 \\
10 \\
11 \\
\text { Geometri } \\
\text { Previous } \\
\text { (infant }\end{array}$ & $\begin{array}{l}40 \\
40 \\
41 \\
40 \\
41 \\
40 \\
41 \\
38 \\
37 \\
37 \\
36 \\
\text { in (log SD) } \\
\text { al NPH geome } \\
16,36-42 \text { wee }\end{array}$ & $\begin{array}{l}1994 \\
3254 \\
3478 \\
3760 \\
2340 \\
3980 \\
2669 \\
3195 \\
2619 \\
1607 \\
2214 \\
\\
\text { tric mean } \\
\text { ks) } 95 \% \text { range }\end{array}$ & $\begin{array}{c}3 \cdot 4 \\
5 \cdot 1 \\
13 \cdot 8 \\
3 \cdot 5 \\
1.4 \\
8 \cdot 5 \\
7 \cdot 2 \\
6.7 \\
1 \cdot 1^{*} \\
8 \cdot 8 \\
11.5 \\
5.9(2 \cdot 0) \\
12.0 \\
5 \cdot 3-27.5\end{array}$ & $\begin{array}{l}3 \cdot 6 \\
18 \cdot 2 \\
10 \cdot 2 \\
10 \cdot 5 \\
3 \cdot 3 \\
11 \cdot 6 \\
24 \cdot 3 \\
17 \cdot 4 \\
0 \cdot 5^{*} \\
26 \cdot 3 \\
23 \cdot 4 \\
12 \cdot 2(2 \cdot 1) \\
36 \cdot 3 \\
14 \cdot 1-58 \cdot 5\end{array}$ & $\begin{array}{c}5 \cdot 7 \\
6 \cdot 5 \\
1 \cdot 4 \\
4 \cdot 2 \\
4 \cdot 5 \\
13 \cdot 0 \\
1 \cdot 3 \\
13 \cdot 2 \\
0 \cdot 5^{*} \\
4 \cdot 7 \\
8 \cdot 8 \\
4 \cdot 7(2 \cdot 2) \\
28 \\
13-41\end{array}$ & Hepatic damage \\
\hline
\end{tabular}

*Interference in analysis giving falsely low values, excluded from mean (SD).

Table 3 Intrapartum asphyxia: clinically moderate or severe cerebral asphyxia with abnormal hypoxanthine excretion

\begin{tabular}{|c|c|c|c|c|c|c|c|}
\hline $\begin{array}{l}\text { Case } \\
\text { No }\end{array}$ & $\begin{array}{l}\text { Gestational } \\
\text { age } \\
\text { (weeks) }\end{array}$ & $\begin{array}{l}\text { Weight } \\
(\mathrm{g})\end{array}$ & Severity of cerebral asphyxia & $\begin{array}{l}\text { Hypoxanthine: } \\
\text { creatinine } \\
\text { ratio }\end{array}$ & $\begin{array}{l}\text { Hypoxanthine } \\
\text { excretion } \\
\text { nmol/hour/kg }\end{array}$ & $\begin{array}{l}\text { Xanthine } \\
\text { excretion } \\
\text { nmol/hour/kg }\end{array}$ & $\begin{array}{l}\text { Assessment } \\
\text { aged } 1 \text { year }\end{array}$ \\
\hline $\begin{array}{l}12 \\
13\end{array}$ & $\begin{array}{l}39 \\
37\end{array}$ & $\begin{array}{l}2610 \\
3470\end{array}$ & $\begin{array}{l}\text { Moderate } \\
\text { Severe and hepatic/renal }\end{array}$ & $32 \cdot 1$ & $9 \cdot 4$ & $5 \cdot 1$ & Doubt \\
\hline $\begin{array}{l}14 \\
15 \\
16 \\
17\end{array}$ & $\begin{array}{l}36 \\
34 \\
34 \\
40\end{array}$ & $\begin{array}{l}2640 \\
2095 \\
2300 \\
3482\end{array}$ & $\begin{array}{l}\text { damage* } \\
\text { Moderate and renal damage* } \\
\text { Moderate } \\
\text { Moderate and renal damage* } \\
\text { Moderate and renal damage* }\end{array}$ & $\begin{array}{l}44 \cdot 7 \\
33 \cdot 6 \\
46 \cdot 5 \\
48 \cdot 4 \\
25 \cdot 7\end{array}$ & $\begin{array}{l}95 \cdot 0 \\
62 \cdot 6 \\
80 \cdot 5 \\
65 \cdot 7 \\
87 \cdot 9\end{array}$ & $\begin{array}{l}82 \cdot 9 \\
33 \cdot 4 \\
35 \cdot 1 \\
31 \cdot 9 \\
41 \cdot 8\end{array}$ & $\begin{array}{l}\text { Died } \\
\text { Normal } \\
\text { Normal } \\
\text { Doubt } \\
\text { Normal }\end{array}$ \\
\hline
\end{tabular}

*By previous criteria.

Table 4 Intrapartum asphyxia: clinically mild cerebral asphyxia with normal development at 1 year and raised hypoxanthine or xanthine excretion

\begin{tabular}{llllll}
\hline Case No & $\begin{array}{l}\text { Gestational age } \\
\text { (weeks) }\end{array}$ & Weight $(\mathrm{g})$ & $\begin{array}{l}\text { Hypoxanthine: } \\
\text { creatinine } \\
\text { ratio }\end{array}$ & $\begin{array}{l}\text { Hypoxanthine } \\
\text { excretion } \\
\text { nmol/hour/kg }\end{array}$ & $\begin{array}{l}\text { Xanthine excretion } \\
\text { nmol/hour/kg }\end{array}$ \\
\hline 18 & 39 & 2610 & $41 \cdot 9$ & $81 \cdot 0$ & $37 \cdot 1$ \\
19 & 33 & 2200 & $38 \cdot 0$ & $20 \cdot 4$ \\
20 & 41 hepatic damage & 3948 & $7 \cdot 0$ & $77 \cdot 8 *$ & $12 \cdot 2$ \\
21 & 41 & 3090 & $1 \cdot 5$ & $6 \cdot 0$ & $73 \cdot 1^{*}$ \\
\hline
\end{tabular}

*Only "abnormal" values. 
Table 5 Intrapartum asphyxia: clinically moderate or severe cerebral asphyxia or abnormal development with normal or equivocal hypoxanthine excretion

\begin{tabular}{|c|c|c|c|c|c|c|}
\hline $\begin{array}{l}\text { Case } \\
\text { No }\end{array}$ & $\begin{array}{l}\text { Gestational } \\
\text { age } \\
\text { (weeks) }\end{array}$ & $\begin{array}{l}\text { Weight } \\
(g)\end{array}$ & $\begin{array}{l}\text { Hypoxanthine: } \\
\text { creatinine } \\
\text { ratio }\end{array}$ & $\begin{array}{l}\text { Hypoxanthine } \\
\text { excretion } \\
\text { nmol/hour/kg }\end{array}$ & $\begin{array}{l}\text { Xanthine } \\
\text { excretion } \\
\text { nmol/hour/kg }\end{array}$ & Assessment aged 1 year \\
\hline $\begin{array}{l}22 \\
23 \\
24 \\
25 \\
26\end{array}$ & $\begin{array}{l}40 \\
34 \\
30 \\
38 \\
39\end{array}$ & $\begin{array}{l}3960 \\
1908 \\
1775 \\
2200 \\
3489\end{array}$ & $\begin{array}{r}23 \cdot 4^{*} \\
11 \cdot 1 \\
9 \cdot 5 \\
4 \cdot 0 \\
7 \cdot 7\end{array}$ & $\begin{array}{l}28 \cdot 7^{*} \\
16 \cdot 0 \\
9 \cdot 6 \\
20 \cdot 3 \\
38 \cdot 5^{*}\end{array}$ & $\begin{array}{c}7 \cdot 8 \\
2 \cdot 8 \\
2 \cdot 6 \\
2 \cdot 8 \\
26 \cdot 6^{*}\end{array}$ & $\begin{array}{l}\text { Abnormal } \\
\text { Doubt, slight } \\
\text { Normal } \\
\text { Normal: growth delay } \\
\text { Normal }\end{array}$ \\
\hline
\end{tabular}

*Values greater than the normal range in table 2.

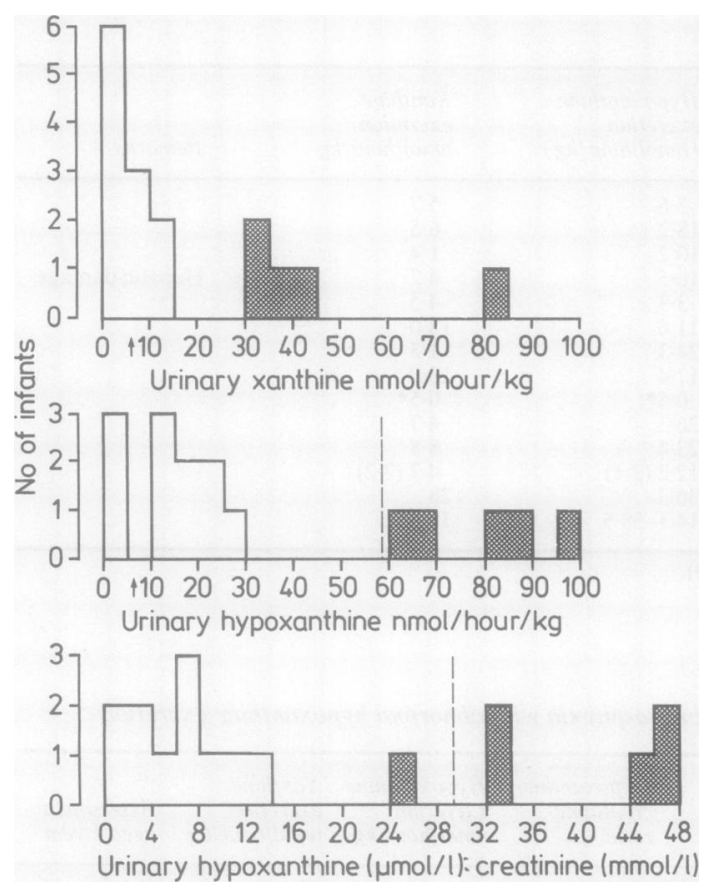

Figure Renal damage in "asphyxiated infants". Distribution of results from tables 2 and 3 of urinary concentration of hypoxanthine:creatinine ratio, the total hypoxanthine and total xanthine excretion/hour/kg body weight. Shaded areas indicate results from patients who were clinically and biochemically abnormal (table 3). had consistently normal hypoxanthine excretion.

The clinical manifestations of cases 22-26 are summarised in table 6 . In case 22 the clinical upset may have been multifactional. Cases 23 and 24 had obstetric evidence of acute ATP depletion: rapid obstetric intervention prevented any tissue damage. Case 25 showed a consistent clinical abnormality, which, our biochemical method suggests, was not due to tissue damage associated with severe ATP depletion.

Despite successful intervention there was slight doubt about development at 1 year of age in case 23 . Case 23 had the only father described as a "labourer" in our series. Only three of 26 infants had fathers who were unemployed, two of whom had some developmental abnormalities at 1 year of age. Otherwise, there was a wide spread of variably skilled occupations among the fathers of the 26 infants studied.

\section{Discussion}

In 17 of $26(69 \%)$ infants there was agreement between the two approaches: to this could be added three other preterm (weighing $<1500 \mathrm{~g}$ ) infants not considered in detail and all of whom had severe asphyxia by previously accepted criteria.

Our results confirm that a quantitative method of estimating tissue damage after ATP depletion is available; and we have extended previous work. ${ }^{12}$ In this study we used a more careful double blind system at two different sites with developmental assessment at 1 year of age. In a concurrent study we also showed that excessive prolonged hypoxanthine excretion

Table 6 Clinical details for cases 22-26 (table 5)

\begin{tabular}{|c|c|c|c|c|c|c|}
\hline Case No & Pregnancy and labour & Mode of delivery & $\begin{array}{l}\text { Severity of } \\
\text { cerebral } \\
\text { asphyxia* }\end{array}$ & $\begin{array}{l}\text { Agpar score } \\
\text { at five minutes }\end{array}$ & $\begin{array}{l}\text { Meconium in } \\
\text { amniotic fluid }\end{array}$ & Other clinical findings \\
\hline 22 & Fetal tachycardia & $\begin{array}{l}\text { Kielland's } \\
\text { forceps }\end{array}$ & 3 & 1 & Yes with aspiration & $\begin{array}{l}\text { Fits, ALT, } 400 \mathrm{u} / \mathrm{l} \text { on da } \\
\text { ? viral encephalopathy }\end{array}$ \\
\hline 23 & Antepartum haemorrhage & $\begin{array}{l}\text { Emergency } \\
\text { caesarian }\end{array}$ & 1 & 9 & No & Rapid recovery \\
\hline 24 & $\begin{array}{l}\text { Spontaneous rupture of } \\
\text { membrane maternal cyanotic } \\
\text { episode }\end{array}$ & Normal & 2 & 9 & Yes with aspiration & Rapid recovery \\
\hline 25 & $\begin{array}{l}\text { Failure to progress fetal heart } \\
\text { rate-prolonged decelerations }\end{array}$ & $\begin{array}{l}\text { Emergency } \\
\text { caesarian }\end{array}$ & 2 & 8 & Yes with aspiration & $\begin{array}{l}\text { Irritable hypertonic ? left } \\
\text { ventricular haemostos }\end{array}$ \\
\hline 26 & $\begin{array}{l}\text { Spontaneous rupture of } \\
\text { membrane fetal heart rate- } \\
\text { prolonged decelerations }\end{array}$ & Normal & 2 & 6 & No & $\begin{array}{l}\text { No neurological signs, } \\
\text { creatinine rose to } 131\end{array}$ \\
\hline
\end{tabular}


occurs after cardiac arrest in older children (unpublished observations).

Severe tissue damage quantitatively similar to that which caused the death of one patient was also associated with only slight doubt about the later development of another patient (case 15). Such variations in outcome and extensive recovery have previously been recognised..$^{192}$ Neonatal mortality and stillbirth rates have fallen over the past $\mathbf{3 0}$ years, but the incidence of cerebral palsy is virtually unchanged. We did not therefore expect and did not find a good correlation between our results for 1 year old babies and the perinatal assessments.

Parental attitudes and stimulation are strong influences on behavioural and intellectual outcome $\mathrm{e}^{2122}$ and can affect growth. ${ }^{23}$ We therefore noted the father's occupation as an indirect assessment of environmental quality and genetic endowment.

The only clear discrepancy between a diagnosis by existing methods and our biochemical method was in one patient (case 26) in whom the hypoxanthine: creatinine ratio was normal but in whom the total hypoxanthine and xanthine excretion were high (figure). The creatinine concentration may have been falsely high due to interference from the colour reaction used.

Previous observations have shown that infants showing definite ATP depletion with increased hypoxanthine concentrations in amniotic fluid ${ }^{24}$ may show no evidence of damage when there is obstetric intervention. This seems the most likely explanation in cases 23 and 24.

The pattern of improvement in survivors of moderate or severe asphyxia (table 3 ) contrasts with the results in table 5. Cases 25 and possibly 23 may have had some additional cause other than ATP depletion for their initial clinical disturbance and later delay in developmental progress.

A completely correct normal range is difficult to establish; the most appropriate values are probably those in table 2 from the infants in the special care baby unit. These values are similar to those from infants in a postnatal ward (table 2) but are not identical; the values from the Edinburgh special care baby unit are lower. This can be explained by differences in nursing technique and environment. The somewhat higher values were obtained from infants nursed in cots in a postnatal ward with an emphasis on securing complete urine collections. In contrast, our infants in a special care unit were nursed in incubators and movement minimised. The consequent reduction in energy expenditure reduced hypoxanthine output. ${ }^{6}$ The low hypoxanthine output from infants treated with special care has also been noted from the Northwick Park Hospital special care baby unit. ${ }^{12}$ Both sets of our results were lower than estimates based on spectrophotometric methods of about 40 $\mathrm{nmol} / \mathrm{hour} / \mathrm{kg}$ body weight. ${ }^{25}$

We identified two infants (cases 18 and 19) in whom oxypurine excretion showed in greater tissue damage than previously accepted estimates. Hypoxanthine excretion seems to be a sensitive measure of tissue damage after ATP depletion because the hypoxanthine:creatinine ratios after moderate or severe asphyxia (table 3 ) were four to eight times the ratios after mild asphxia (table 2). In a recent study of renal damage after perinatal asphyxia urinary $\mathrm{N}$-acetyl- $\beta \mathrm{D}$ glucosaminidase, a sensitive marker of renal tubular damage, only increased about fourfold. Measurements related to glomerular filtration rate only doubled or halved. ${ }^{26}$

The biochemical basis of our method is ill understood in contrast to the clear understanding of the use of hypoxanthine output to measure acute ATP depletion. Persistent excessive hypoxanthine output may be linked to the failure of damaged tissues to maintain their total adenine nucleotide concentrations. ${ }^{10}$

Having established and confirmed in the present study the validity of the biochemical method, ${ }^{12}$ the next task is to examine its possible role(s) in clinical practice. Widespread routine use seems inappropriate in infants who have had a clear cause of asphyxia, like a prolapsed cord, or pronounced effects of asphyxia like fits. We defined a small group of about $0 \cdot 1 \%$ of all births (tables 5 and 6 ) in whom further detailed investigation may be justifiable. Cases 23 and 25 who showed some developmental abnormality (table 5) may have some additional reason for such persistent problems. Our results are consistent with evidence from less direct and less sensitive methods, suggesting that about half the children with cerebral palsy may not have had intrapartum asphyxia. ${ }^{1927}$ Furthermore, in patients initially diagnosed as having the effects of intrapartum asphyxia we have already retrospectively found patients with congenital adrenocortical hypoplasia, ${ }^{28}$ septo-optic dysplasia, and the Lesch Nyhan syndrome.

Our results are consistent with epidemiology which shows that many cases of cerebral palsy are probably not due to cerebral asphyxia as was thought previously; in 1987 Stanley concluded that the use of cerebral palsy to evaluate perinatal practice should be questioned. ${ }^{29}$

Our results for hypoxanthine excretion agree with previously used criteria with a few interesting exceptions. By sensitively measuring asphyxial damage, which is common, those few sick infants who do not have sufficient asphyxial damage to account for their clinical findings, especially developmental delay, and who therefore require further investigation for rarer disorders like inherited metabolic diseases, congenital defects with and without chromosomal anomalies, 
infestations or infections, can more readily be identified.

\section{References}

1 Paneth N, Stark RI. Cerebral palsy and mental retardation in relation to indicators of perinatal asphyxia. An epidemiologic overview. Am J Obstet Gynecol 1983;147:960-6.

2 Addy DP. Birth asphyxia. Br Med J 1982;284:1288-9.

3 Sykes GS, Molloy PM, Johnson P, Stirrat GM, Turnbull AC. Fetal distress and the condition of newborn infants. $\mathrm{Br} \mathrm{Med} \mathrm{J}$ 1983;287:943-5.

4 Harkness RA, Lund RJ. Cerebrospinal fluid concentrations of hypoxanthine, xanthine, uridine and inosine: high concentrations of the ATP metabolite hypoxanthine after hypoxia. J Clin Pathol 1983;36:1-8.

5 Bejar R, Saugsted OD, James H, Gluck L. Increased hypoxanthine concentrations in cerebrospinal fluid of infants with hydrocephalus. J Pediatr 1983;103:44-8.

6 Harkness RA, Simmonds RJ, Coade SB. Purine transport and metabolism in man: the effect of exercise on concentrations of purine bases, nucleosides and nucleotides in plasma, urine leucocytes and erythrocytes. Clin Sci 1983;64:333-40.

7 Harkness RA, Coade SB, Walton KR, Wright D. Xanthine oxidase deficiency and "Dalmatian" hypouricaemia: incidence and effect of exercise. J Inher Metab Dis 1983;6:114-20.

8 Hallgren R, Niklasson F, Terent A, Akerblom A, Widerlov E. Oxypurines in cerebrospinal fluid as indices of disturbed brain metabolism. Stroke 1983;14:382-8.

9 Levin SD, Brown JK, Harkness RA. Cerebrospinal fluid hypoxanthine and xanthine concentrations as indicators of metabolic damage due to raised intracranial pressure in hydrocephalic children. J Neurol Neurosurg Psychiatry 1984;47:730-3.

10 Warnick CT, Lazarus HM. Recovery of nucleotide levels after cell injury. Can J Biochem 1981;59:116-21.

11 Kloner RA, Granote E, Whalen DA, Jennings RB. Effect of a transient period of ischaemia on myocardial cells. Am J Pathol 1974;74:399-422.

12 Harkness RA, Whitelaw AGL, Simmonds RJ. Intrapartum hypoxia: the association between neurological assessment of damage and abnormal excretion of ATP metabolites. J Clin Pathol 1982;35:999-1007.

13 Harkness RA, Simmonds RJ, Coade SB, Lawrence CR. Ratio of the concentration of hypoxanthine to creatinine in urine from newborn infants: a possible indicator for metabolic damage due to hypoxia. Br J Obstet Gynaecol 1983;90:447-52.

14 Hon EH. Fetal heart rate monitoring. In: Spellacy WN, ed. Management of the high risk pregnancy. Baltimore: University Park Press, 1976:237-52.

15 Neutra RR, Greenland S. Continuous intrapartum electronic fetal monitoring. In: Wald NJ, ed. Antenatal and neonatal screening. Oxford: Oxford University Press, 1984:480-509.

16 Capute AJ, Biehl RF. Functional and developmental evaluation. Pediatr Clin North Am 1973;20:3-26.

17 Simmonds RJ, Harkness RA. High performance liquid chromatographic methods for base and nucleoside analysis in extracellular fluids and in cells. Journal of Chromatography Biomedical Applications 1981;226:369-81.

18 Coulthard MG, Hey EN. Weight as the best standard for $\bar{G}$ glomerular filtration in newborn. Arch Dis Child 1984;59:373-5.

19 Nelson KB, Ellenborg JH. Apgar scores as predictors of chronic disability. $J$ Pediatr 1981;68:36-44.

20 Ergander U, Eriksson M, Zetterstrom R. Severe neonatal asphyxia incidence and prediction of outcome in the Stockholm . area. Acta Paediatr Scand 1983;72:321-5.

21 Marjoribanks K. Environment, social class, mental abilities. Journal of Educational Psychology 1972;43:103-9.

22 Elardo R, Bradley RM, Caldwell BM. The relation of the infants home environment to mental test performance at six and thirtysix months. A longitudinal analysis. Child Dev 1975;46:71-6.

23 Sonksen PH, West TET. Growth hormone. In: Gray $\mathbf{C H}$, James $\omega$ VHT, eds. Hormones in blood. 3rd ed. London: Academic Press, N 1979:225-54.

24 Harkness RA, Geirsson RT, McFayden IR. Concentrations of hypoxanthine, xanthine, uridine and urate in amniotic fluid at caesarian sections and the association of raised levels with prenatal risk factors and fetal distress. Br J Obstet Gynaecol 1983;90:815-20.

25 Jensen MH, Jorgensen S. Oxypurine excretion of normal newborn infants. Biol Neonate 1977;32:197-207.

26 Kojima T, Kobayashi T, Matsuzaki S, Iwase S, Kovayashi Y. Effects of perinatal asphyxia and myoglobinuria on development of acute neonatal renal failure. Arch Dis Child 1985;60:908-12.

27 Dijxhoorn MJ, Visser GHA, Fidler VJ, Touwen BCL, Huisjes HJ. Apgar score, meconium and acidaemia at birth in relation to neurological morbidity in term infants. Br J Obstet Gynaecol 1986;93:217-22.

28 Harkness RA, Taylor NF, Bowman PR, Gordon H, Cummins M Valman HB. The causes of low oestrogen excretion in pregnancy: the development of diagnostic methods for the antenatal detection of familial congenital adenocortical hypoplasia. Clin Endocrinol 1980;12:453-560.

29 Stanley FJ. The changing face of cerebral palsy. Dev Med Child Neurol 1987;29:258-70.

Requests for reprints to: Dr R A Harkness, Division of Inherited Metabolic Diseases, MRC Clinical Research Centre, Watford Road, Harrow, Middlesex HAl 3UJ, England. 